\title{
PRELIMINARY CHECKLIST OF THE HERPETOFAUNA OF THE UPPER RIO URUCU, AMAZONAS, BRAZIL
}

\author{
Claude Gascon 1,2 \\ Ocírio de Souza Pereira ${ }^{2}$
}

\begin{abstract}
Thirty-three species of anuran amphibians and 22 species of reptiles were found in 9 days and nights of sampling in an unexplored region of Central Amazon. The community is characterized by typical lowland Amazonian species. The relatively short sampling time and high number of species caught indicates that this region probably has very high species richness.

KEY WORDS. Checklist, herpetofauna, Rio Urucu, Amazonas, Brazil
\end{abstract}

A few herpetofaunal communities in the Amazon are relatively wellknown; Belém, Brazil (CRUMP, 1971), Manaus, Brazil (HODL, 1977; ZIMMERMAN; RODRIGUES, 1990); Madeira and Purus rivers, Brazil (HEYER,1977); French Guiana (LESCURE, 1976, 1986), Panguana, Peru (TOFT \& DUELLMAN, 1979), Santa Cecília, Ecuador (CRUMP, 1974; DUELLMAN, 1978). However, on the whole very little of the Amazon has been surveyed, and it is specially true for the brazilian Amazon (CRUMP, 1971; ZIMMERMAN \& RODRIGUES, 1990). Outside Brazil, many more Amazonian sites have been surveyed (see DUELLMAN, 1988 for review). Detailed biogeographic analysis of herpetofaunal community composition will require surveys at a large number of additional sites throughout the Amazon.

Herein, we report the results of a survey of a herpetofaunal community for one site in the brazilian Amazon located in a large unexplored region of the Amazon (DUELLMAN, 1988). The date are valuable although only part of the herpetofaunal community of that region is explored. Because of the difficulty of sampling reptiles, this sample is obviously not representative of the whole community found at that site. Therefore, discussion in this paper will be limited to the amphibian data although the species list includes all herpetofauna for reference purposes.

\section{MATERIAL AND METHODS}

Field work was carried out in primary tropical forest, $3 \mathrm{~km}$ south of the headwaters of the Urucu river $\left(4^{\circ} 60 \mathrm{~S}, 65^{\circ} 30 \mathrm{~W}\right)$ along a small tributary of the

1) Department of Zoology, University of Guelph, Guelph, Ontario N1G 2W1 Canada.

2) Projeto PDBFF, Departamento de Ecologia, Instituto Nacional de Pesquisas da Amazônia, Caixa Postal 478, 69011-970 Manaus, Amazonas, Brasil. 
Solimōes, south of Tefé. The forest in this area is typical "terra firme"forest (forest not subjected to periodic flooding). The area surveyed comprised approximately 200 hectares of smooth rooling hills with many 1 st order streams (PERES \& WHITTAKER, in press). One large stream (8 meters wide) cut the area toward the western side. Many stream-side ponds are associated with the numerous streams especially along the large stream bank. The stream-side ponds are either periodically flooded by the overflowing streams or are filled by heavy rains. Very few isolated forest pools were found.

Sampling was done by day and night and all herpetofauna encountered was collected. Interesting sites were noted and night visits were made to those sites. Also, choruses were located and calls of those species were recorded and individuals collected. Sampling was done over 9 days and nights (from 14-V-1989 to $22-\mathrm{V}-1989$ ) totaling 110 man-hours of survey ( 36 by day and 74 by night) and $30 \mathrm{~km}$ of trails walked ( 10 by day and 20 by night).

All material collected is deposited either in the National Museum of Rio de Janeiro (MNRJ) or at the Instituto Nacional de Pesquisas da Amazonia (INPA). Appendix 1 gives the museum numbers for the collected material. Phrynohyas sp. and Hila boans were identified only from calling individuals.

\section{RESULTS}

Thirty-three species of frogs of six different families were collected (Table I). Hylids were the most common frogs with 15 species ( $46 \%$ of all species collected) followed by leptodactylids with 8 species ( $24 \%$ of all species). Five dendrobatid species were collected (15\%). Finally, 3 Bufonidae (9\%), 1 Pipidae (3\%) and 1 Microhylidae (3\%) complete the species list.

Sites adjacent to the large stream were the only ones where Hyla boans and Phrynohyas sp. were heard calling. The most common species calling was Leptodactylus wagneri which was omnipresent. Although Osteocephalus taurinus was not heard calling it also was collected over most of the area.

\section{DISCUSSION}

Almost all species found are typical lowland Amazonian species with wide rangers (FROST, 1985). Although only a relatively short time was spent surveying the study site, sampling was intensive. The fairly high number of species of frogs caught (33) in such a short period of time probably reflects very high species richness in that area (Table II). The only other study for which detailed capture rates of species is available (ZIMMERMAN \& RODRIGUES, 1990 ) shows that after 110 man-hours that survey had encountered less that 20 species whereas this study has found 33 species. Also, only primary forest was surveyed in this study whereas in many of the other studies the surveys included primary forest areas and various other types of habitats: secondary forest and swamp area in TOFT \& DUELLMAN (1979), secondary forest as well as large river areas in CRUMP (1971), swamp areas as well as nearby agricultural lands 
Table I. Preliminary species list of the upper Urucu river.

\begin{tabular}{|c|c|}
\hline SPECIES & SPECIES (continued) \\
\hline HYLIDAE & Bufo sp. \\
\hline Hyla calcarata & PIPIDAE \\
\hline Hyla fasciata & Pipa pipa \\
\hline Hyla geographica & MICROHYLIDAE \\
\hline Hyla lanciformis & Chiasmocleis sp. \\
\hline Hyla leucophylata & TEIIDAE \\
\hline Hyla parviceps & Alopoglosus angulatus \\
\hline Hyla boans & Ameiva ameiva \\
\hline Hyla sp.1 & Leposoma percarinatum \\
\hline Hyla sp. 2 & SCINCIDAE \\
\hline Hyla sp.3 & Mabuya bistriata \\
\hline Ololygon rubra & IGUANIDAE \\
\hline Ololygon sp. grupo rubra & Anolis chrysolepis \\
\hline Osteocephalus taurinus & Anolis fuscoauratus \\
\hline Phrynohyas sp. & Anolis ortonii \\
\hline Phryllomedusa vaillanti & Anolis punctatus \\
\hline LEPTODACTYLIDAE & Anolis cf. punctatus \\
\hline Leptodactylus wagneri & Anolis sp. \\
\hline Leptodactylus pentadactylus & Uranoscodon supercilisosus \\
\hline Leptodactylus rhodomystax & GEKKONIDAE \\
\hline Adenomera andreae & Coleodactylus amazonicus \\
\hline Physalaemus petersi & COLUBRIDAE \\
\hline Eleutherodactylus fenestratus & Atractus sp. \\
\hline Eleutherodactylus sp.1 & Leptodeira annulata \\
\hline Eleutherodactylus sp. 2 & Oxyrhopus cf. melanogenys \\
\hline DENDROBATIDAE & Rhadinaea sp. \\
\hline Colostethus sp. grupo marchesianus & Xenodon severus \\
\hline Epipedobates femoralis & Xenopholis scalaris \\
\hline Epipedobates pictus & VIPERIDAE \\
\hline Epipedobates trivittatus & Bothrops atrox \\
\hline Epipedobates quinquevitatus & Bothrops brazilii \\
\hline BUFONIDAE & BOIDAE \\
\hline Bufo marinus & Corallus caninus \\
\hline Bufo typhonius & Corallus enydris \\
\hline
\end{tabular}


Table II. Species richness of various amazonian primary forest sites.

\begin{tabular}{|c|c|c|c|c|}
\hline Site & Reference & Species richness & Sampling effort & Area \\
\hline \multicolumn{5}{|l|}{ BRAZIL } \\
\hline Rondônia & Vanzolini, 1986 & 70 & 80 days & $\begin{array}{c}3500 \mathrm{~km} \text { of } \\
\text { transects }\end{array}$ \\
\hline Manaus & $\begin{array}{c}\text { Zimmerman \& } \\
\text { Rodrigues, } 1990\end{array}$ & 42 & 400 hours & 3000 ha \\
\hline Belém & Crump, 1971 & 37 & - & - \\
\hline Urucu & This study & 33 & $\begin{array}{c}110 \text { hours } / 30 \mathrm{~km} \\
\text { trails }\end{array}$ & 200 ha \\
\hline \multicolumn{5}{|l|}{ ECUADOR } \\
\hline Santa Cecilia & Crump, 1974 & 81 & 23 months & 300 ha \\
\hline \multicolumn{5}{|l|}{ PERU } \\
\hline Panguana & Toft \& Duellman, 1979 & 53 & $1969-1975$ & - \\
\hline Panguana & Aichinger, 1987 & 46 & 12 months & 200 ha \\
\hline \multicolumn{5}{|c|}{ FRENCH GUIANA } \\
\hline & Lescure, 1976 & 57 & - & - \\
\hline
\end{tabular}

in CRUMP (1974), nearby cleared areas in AICHINGER (1987). The actual primary forest species richness in those studies would therefore be lower than the values given in table II.

Results from this study stress the importance of additional surveys of herpetofaunal communities especially in the brazilian Amazon. More detailed knowledge of species distribuition and areas of high species richness and endemism will greatly aid in attempts to conserve high species diversity of this vertebrate.

ACKNOWLEDGMENTS. This study was supported by World Wildlife Fund, The Instituto Nacional de Pesquisas da Amazônia, Smithsonian Institution, Sigma Xi, The Scientific Research Society. Additional support was provided from a Graduate Fellowship from FCAR (Quebec). Support during the preparation of the manuscript was provided by grant \# BSR 88-18001 to J. Travis and an NSERC (Canada) post-doctoral fellowship to CG. The authors wish to thank M. Rodrigues, U. Caramaschi, and M. Hoogmoed for identification of specimens, and J. Travis for reviewing the manuscript. We also wish to thank $\mathrm{C}$. Peres and Petrobras for logistic help and allowing us to access the area. This is publication \# 85 of the Biological Dynamics of Tropical Forest Fragments Project.

\section{BIBLIOGRAPHIC REFERENCES}

AICHINGER, M. 1987. Annual activity patterns of anurans in a seasonal neotropical environment. Oecologia 71: 583-592.

CRUMP, M.L. 1971. Quantitative analysis of the ecological distribution of a 
tropical herpetofauna. Occas Pap. Mus. Nat. Hist. Univ. Kansas 3: 1-62.

. 1974. Reproductive strategies in a tropical anuran community. Misc. Pub. Mus. Nat. Hist. Univ. Kansas 61: 1-68.

DUELLMAN, W.E. 1978. The biology of an equatorial herpetofauna in amazonian Ecuador. Misc. Pub. Mus. Nat. Hist. Univ. Kansas 65: 1-485.

- 1988. Patterns of species diversity in anuran amphibians in the American tropics. Ann. Mis. Bot. Garden 75: 79-104.

FROST, D.R. 1985. Amphibian species of the world. Lawrence Kansas, Assoc. Syst. Coll. V +732p.

HEYER, W.R. 1977. Taxonomic notes on frogs from the Madeira and Purus Rivers, Brazil. Pap. Avul. Zool., S. Paulo, 31: 141-162.

HÖDL, W.R. 1977. Call differences and calling site segregation in anuran species from Central Amazonian floating meadows. Oecologia 28: 351-363.

LESCURE, J. 1976. Contribuition à 1 étude de amphibiens de Guyane Française. 6. Liste préliminaire des Anoures. Bull. Mus. Natl. Hist. Nat. Paris (Zool.) 265: 475-524.

- 1986. Les amphibiens Anoures de la forêt guyanaise (région des Trois-Sauts, Guyane Française). Mem. Mus. Natt. Hist. Nat. (Zool.) 132: 43-52.

PERES, C.A. \& A. WHITTAKER. In Press. Annotated checklist of the bird species of the upper Rio Urucu, Amazonas, Brazil. Bull. British ornit. Club: $1-23$.

TOFT. C.A. \& W.E. DUELLMAN. 1979. Anurans of the lower Rio Llullapichis, Amazonian Peru: a preliminary analysis of community structure. Herpetologica 35: 71-77.

VANZOLINI, P.E. 1986. Levantamento herpetológico da área do estado de Rondônia sob influência da rodovia BR 364. Relatório de Pesquisa $\mathrm{n}^{\mathrm{Q}} 1$. Brasília, CNPq, Assessoria Editorial, 50p.

ZIMMERMAN, B.L. \& M.T. RODRIGUES. 1990. Frogs, Snakes and Lizards of the INPA-WWF reserves near Manaus, Brazil. In: A. GENTRY (ed.). Four Neotropical Forests. New Haven, Yale Univ. Press.

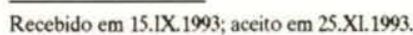

